\title{
ASSESSMENT OF ANTIMICROBIAL ACTIVITY IN DIPLOSTEPHIUM PHYLICOIDES AND DIPLOSTEPHIUM REVOLUTUM EXTRACTS BY PLATES AND WELLS METHOD
}

\section{JANETH DEL CARMEN ARIAS PALACIOS ${ }^{1 *}$, LEONARDO PEÑA CARRANZA ${ }^{1}$, NATALIA PAOLA TORRES NIÑO ${ }^{1}$, OSCAR EDUARDO RODRÍGUEZ AGUIRRE ${ }^{2}$}

${ }^{1}$ Department of Microbiology, Faculty of Sciences, Pontificia Universidad Javeriana, Bogotá, Colombia. ${ }^{2}$ Environmental Engineering Program, Faculty of Engineering, Universidad El Bosque, Research Group CHOC-IZONEC, Bogotá, Colombia. Email: jdcarias@javeriana.edu.co

Received: 02 November 2019, Revised and Accepted: 05 December 2019

ABSTRACT

Objective: The evaluation of the antimicrobial activity of Diplostephium phylicoides and Diplostephium revolutum on different microorganisms was carried out on using bacteria such as Escherichia coli (CMPUJ:034), Staphylococcus aureus (CMPUJ:370), Salmonella typhi (CMPUJ:045), and Pseudomonas aeruginosa (CMPUJ:065); yeasts such as Saccharomyces cerevisiae (CMPUJ: H042) and Candida albicans (CMPUJ: H022); and filamentous fungi such as Penicillium chrysogenum (CMPUJ: H061) and Aspergillus niger (CMPUJ: H002).

Methods: This assessment was made by the method of plates and wells using extracts from the leaves of the previously mentioned plants. The extracts were made with different solvents, ethanol, ethyl acetate, dichloromethane, and petroleum ether.

Results: The results showed that the ethyl acetate extract of D. phylicoides has antimicrobial activity against $S$. aureus and C. albicans; furthermore, the dichloromethane extract showed an inhibitory effect against $S$. cerevisiae.

Conclusions: When comparing the extracts of the two plants, under the evaluated conditions, the extracts presented antimicrobial activity and the ethyl acetate extract of $D$. revolutum the one that showed better activity against all the microorganisms.

Keywords: Antimicrobial, Diplostephium phylicoides, Diplostephium revolutum, Extracts, Solvents, Plates and wells.

(C) 2020 The Authors. Published by Innovare Academic Sciences Pvt Ltd. This is an open access article under the CC BY license (http://creativecommons. org/licenses/by/4. 0/) DOI: http://dx.doi.org/10.22159/ajpcr.2020.v13i1.36252

\section{INTRODUCTION}

According to the World Health Organization, antibiotic resistance is increased by the misuse and abuse of drugs, as well as with the deficiencies in the prevention and control of infections [1]. However, an alternative solution is the development of drugs that are not only effective in their antimicrobial activity but is also accessible to the entire population.

Phytomedicines are identified as a viable option, because plants, in their survival nature, produce secondary metabolites such as terpenes, phenols, flavonoids, quinines, tannins, and alkaloids [2]. These are obtained by making plant extracts, which have been identified to possess antimicrobial activity and have been previously used for the production of phytomedicines, which like synthetic drugs, are able to treat, cure, or alleviate diseases. Furthermore, phytomedicines represent a great opportunity since it is possible to develop them with endemic plants, which are exclusive to a region. For this reason, it is important to identify the plants that produce the secondary metabolites required to guarantee effective phytomedicines. Some native plants that may exhibit these properties belong to the genus Diplostephium [3-5].

Diplostephium phylicoides (H. B. K.) Wedd. and Diplostephium revolutum are species exclusive to the páramos (high Andean moors) of the departments of Cundinamarca and Boyacá, at altitudes between 3000 and $4000 \mathrm{~m}[6,7]$. They are low bushes that have dense woolly foliar branches and dense leaves with oval and oblong shapes. They have showy capitula with violet or white ligules [6,7]. Secondary metabolites such as triterpenes (uvaol, bauerenol acetate, and friedelin) and flavonoids (genkwanin, quercetin, and sorbifolin) have been found from extracts of $D$. phylicoides, in which antioxidant and antimicrobial activity has been reported [8]. In the present study, we evaluated the antimicrobial activity of leaf extracts from $D$. phylicoides and D. revolutum plants against Escherichia coli, S. aureus, Salmonella typhi, and Pseudomonas aeruginosa bacteria; Saccharomyces cerevisiae and Candida albicans yeasts; and the filamentous fungi Penicillium chrysogenum and Aspergillus niger.

\section{METHODS}

Microorganism

E. coli (CMPUJ:034), S. aureus (CMPUJ:370), S. typhi (CMPUJ:045), P. aeruginosa (CMPUJ:065), S. cerevisiae (CMPUJ: H042), C. albicans (CMPUJ: H022), P. chrysogenum (CMPUJ: H061), and A. niger (CMPUJ: $\mathrm{H} 002$ ) used in the study were obtained from the microorganism bank of the Pontificia Universidad Javeriana.

\section{Preparation of extracts}

The plants used in the study were collected along the road between Bogotá and Guasca in a place known as the páramo de Chingaza (Cundinamarca, Colombia). The extraction process was carried out with the leaves of each plant separately, by hot extraction method in Soxhlet extraction and using as solvents petroleum ether, dichloromethane, ethyl acetate, and ethanol. These extracts were concentrated under reduced pressure using a rotary evaporator at a temperature of $40^{\circ} \mathrm{C}[9-11]$ and they were solubilized and brought to a concentration of $100 \mathrm{mg} / \mathrm{mL}$ in dimethyl sulfoxide (DMSO) for later use.

\section{Preparation of inoculums}

From the microorganisms obtained in Potato Dextrose Agar (PDA) and Nutrient Agar for fungi and bacteria, respectively, isolated colonies (approximately $1 / 4$ from the box) were taken and added to a tube with sterile peptone water, which is used for the recovery of the microorganisms, until obtaining a turbidity corresponding to a transmittance of $25 \%$. The fungi inoculums were diluted to a concentration of $10^{6}$ cells $/ \mathrm{ml}$. 
Preparation of culture media

For the preparation of Nutrient Agar (composition) used for bacterial growth, $14.38 \mathrm{~g}$ of commercial NA was weighed and added to an Erlenmeyer with $626 \mathrm{~mL}$ of distilled water under constant agitation and temperature. In the case of PDA (composition) used for fungi and yeast growth, $24.38 \mathrm{~g}$ of commercial PDA was weighed and added to an Erlenmeyer with $626 \mathrm{~mL}$ of distilled water under constant agitation and temperature. Both Erlenmeyer were agitated until the media were completely homogenized with the water and the media were sterilized in an autoclave at $121^{\circ} \mathrm{C}$.

\section{Preparation of controls}

DMSO was used as negative control in each microorganism and as positive control, an antibiotic (Gibco ${ }^{\mathrm{TM}}$ - Thermo Fisher scientific) and a commercial antifungal (Quirucidal ${ }^{\circledR}$ - QUIRUMEDICAS) were used for bacteria and fungi, respectively. The antibiotic was brought to a concentration of $5 \mathrm{X}$ and the antifungal to a concentration of $2 \%(\mathrm{w} / \mathrm{v})$. In each control, a volume of $20 \mu \mathrm{l}$ was used.

\section{Preparation and identification of Petri dishes}

From the inoculums made, an aliquot of $62.5 \mathrm{~mL}$ was taken and added in $562.5 \mathrm{~mL}$ of sterile heated NA or PDA. Subsequently, approximately $25 \mathrm{~mL}$ of medium inoculated with the strain was added to the Petri dish and the agar layer was left to solidify. With the medium already solid, five perforations were made in the agar, from the surface of the agar to the base of the plate with an inverted pipette. Finally, the extracts were added in different volumes in four wells $(10 \mu \mathrm{l}, 20 \mu \mathrm{l}$, $30 \mu \mathrm{l}$, and $50 \mu \mathrm{l}$ ) and in the last well, $20 \mu \mathrm{l}$ of the positive control was added.

\section{Relative percentage of inhibition (RPI)}

At the end of the incubation time, the inhibition halos obtained in each well were measured. The inhibition halos were expressed in millimeters $(\mathrm{mm})$ and the antimicrobial activity was determined as an RPI using the following formula [11]:

$$
\mathrm{RPI}=\frac{\mathrm{Di}-\mathrm{Dn}}{\mathrm{Dp}-\mathrm{Dn}} \times 100
$$

Where, Di is the diameter of the inhibition zone of the extract, Dn is the inhibition zone diameter of the negative control, and Dp is the diameter of the inhibition zone of the positive control, which were antibiotic $\left(\right.$ Gibco $^{\mathrm{TM}}$ - Thermo Fisher scientific) and antifungal (Quirucidal ${ }^{\circledR}$ QUIRUMEDICAS) commercial for bacteria and fungi, respectively.

\section{Statistical analysis}

All experiments were performed in triplicates $(n=3)$. A design was developed for which the assumptions of compliance with the parametric statistics were determined by performing tests of normality (Shapiro-Wilk) and variance (Levene). An analysis of variance was performed together with Tukey and post hoc tests for comparison of means to determine significant differences. The test was performed in the R statistical software.

\section{RESULTS}

In this study, the antimicrobial activity of leaf extracts of D. phylicoides and $D$. revolutum was evaluated using the plate and well method on a set of microorganisms: Bacteria (E. coli, S. aureus, S. typhi, and $P$. aeruginosa), filamentous fungi (P. chrysogenum and $A$. niger), and yeasts (S. cerevisiae and C. albicans), considering the solvent (petroleum ether, dichloromethane, ethyl acetate, and ethanol) and volumes used $(10 \mu \mathrm{l}, 20 \mu \mathrm{l}, 30 \mu \mathrm{l}$, and $50 \mu \mathrm{l})$ as factors of variation in the inhibition response.

The negative control showed no antimicrobial activity against the study microorganisms, while the positive controls showed antimicrobial activity, which was variable depending on the microorganism. In addition, for each experiment, the RPI was calculated.

\section{Diplostephium phylicoides}

\section{Bacteria}

Leaf extract from ethyl acetate of $D$. phylicoides showed significant antibacterial activity, as shown in Table 1, as it recorded inhibitory activity in three of the four bacteria used in this study, presenting an inhibition percentage of $32.015 \%$ on the bacterium S. aureus (Figs. 1a and 2), being this bacterium the one that presented sensitivity to all extracts. Regarding the other extracts, no antimicrobial activity was recorded in E. coli, S. typhi, and P. aeruginosa. In addition, no halo of inhibition was recorded on E. coli bacteria, demonstrating their resistance to the different extracts.

\section{Fungus}

Table 2 shows the antimicrobial activity on fungi and is observed that, in general, leaf extracts of $D$. phylicoides presented antifungal activity on the set of microorganisms, presenting greater activity on S. cerevisiae. Yeasts were more sensitive to extracts, S. cerevisiae being the most sensitive, while $A$. niger was the least sensitive filamentous fungus.

Dichloromethane extract showed inhibition against the fungi and yeasts used. In addition, this extract presented an elevated inhibition

Table 1: Average inhibition percentage of Diplostephium phylicoides leaf extracts on bacteria

\begin{tabular}{|c|c|c|c|}
\hline Bacteria & Extract & $\begin{array}{l}\text { Mean } \\
\text { percentage } \\
\text { inhibition }\end{array}$ & $\begin{array}{l}\text { Percentage } \\
\text { inhibition } \\
\text { variance }\end{array}$ \\
\hline Escherichia coli & $\begin{array}{l}\text { Petroleum ether } \\
\text { Dichloromethane } \\
\text { Ethyl acetate } \\
\text { Ethanol }\end{array}$ & & \\
\hline $\begin{array}{l}\text { Staphylococcus } \\
\text { aureus }\end{array}$ & $\begin{array}{l}\text { Petroleum ether } \\
\text { Dichloromethane } \\
\text { Ethyl acetate } \\
\text { Ethanol }\end{array}$ & $\begin{array}{l}3.945 \\
11.403 \\
32.015 \\
4.320\end{array}$ & $\begin{array}{l}0.509 \\
0.948 \\
2.995 \\
0.429\end{array}$ \\
\hline $\begin{array}{l}\text { Salmonella } \\
\text { typhi }\end{array}$ & $\begin{array}{l}\text { Petroleum ether } \\
\text { Dichloromethane } \\
\text { Ethyl acetate } \\
\text { Ethanol }\end{array}$ & 3.573 & 0.418 \\
\hline $\begin{array}{l}\text { Pseudomonas } \\
\text { aeruginosa }\end{array}$ & $\begin{array}{l}\text { Petroleum ether } \\
\text { Dichloromethane } \\
\text { Ethyl acetate } \\
\text { Ethanol }\end{array}$ & 3.333 & 0.606 \\
\hline
\end{tabular}

Table 2: Average inhibition percentage of Diplostephium phylicoides leaf extracts on fungi

\begin{tabular}{llll}
\hline Fungi & Extract & $\begin{array}{l}\text { Mean } \\
\text { percentage } \\
\text { inhibition }\end{array}$ & $\begin{array}{l}\text { Percentage } \\
\text { inhibition } \\
\text { variance }\end{array}$ \\
\hline $\begin{array}{l}\text { Candida } \\
\text { albicans }\end{array}$ & Petroleum ether & & \\
& Dichloromethane & 8.333 & 2.778 \\
& Ethyl acetate & 15.278 & 10.838 \\
Saccharomyces & Ethanol & 12.500 & 5.619 \\
cerevisiae & Petroleum ether & & \\
& Dichloromethane & 43.333 & 11.515 \\
& Ethyl acetate & 23.333 & 12.242 \\
Penicillium & Ethanol & 11.667 & 7.606 \\
chrysogenum & $\begin{array}{l}\text { Petroleum ether } \\
\text { Dichloromethane }\end{array}$ & 6.944 & 2.757 \\
& Ethyl acetate & 15.278 & 5.787 \\
Ethanol & & \\
& Petroleum ether & & \\
& Dichloromethane & 11.111 & \\
& Ethyl acetate & & \\
& Ethanol & & \\
\hline & & & \\
\hline
\end{tabular}


percentage on S. cerevisiae of $43.33 \%$ (Table 2 and Fig. 1b). The yeasts $S$. cerevisiae and C. albicans presented sensitivity to the different extracts, so defined inhibition halos could be observed (Figs. 3 and 4). On S. cerevisiae, an antimicrobial effect is evidenced with the ethyl acetate and dichloromethane extracts, the other extracts do not present significant activity. Petroleum ether extract has no significant effect on $C$. albicans, while ethanol has the highest inhibition percentage (Table 2 and Fig. 1c).

Table 3: Average inhibition percentage of Diplostephium revolutum leaf extracts on bacteria

\begin{tabular}{llll}
\hline Bacteria & Extract & $\begin{array}{l}\text { Mean } \\
\text { percentage } \\
\text { inhibition }\end{array}$ & $\begin{array}{l}\text { Percentage } \\
\text { inhibition } \\
\text { variance }\end{array}$ \\
\hline Escherichia coli & Ethyl acetate & 16.668 & 6.182 \\
Staphylococcus aureus & Ethyl acetate & 25.440 & 0.646 \\
Salmonella typhi & Ethyl acetate & 18.253 & 0.612 \\
Pseudomonas & Ethyl acetate & 43.889 & 3.593 \\
aeruginosa & & & \\
\hline
\end{tabular}

Table 4: Average inhibition percentage of Diplostephium revolutum leaf extracts on fungi

\begin{tabular}{|c|c|c|c|}
\hline Fungi & Extract & $\begin{array}{l}\text { Mean } \\
\text { percentage } \\
\text { inhibition }\end{array}$ & $\begin{array}{l}\text { Percentage } \\
\text { inhibition } \\
\text { variance }\end{array}$ \\
\hline Candida & Petroleum ether & 8.333 & 2.778 \\
\hline \multirow[t]{3}{*}{ albicans } & Dichloromethane & 6.667 & 2.424 \\
\hline & Ethyl acetate & 11.112 & 6.735 \\
\hline & Ethanol & 12.500 & 5.619 \\
\hline \multirow{4}{*}{$\begin{array}{l}\text { Saccharomyces } \\
\text { cerevisiae }\end{array}$} & Petroleum ether & & \\
\hline & Dichloromethane & & \\
\hline & Ethyl acetate & 11.112 & 6.735 \\
\hline & Ethanol & 11.667 & 7.606 \\
\hline \multirow{3}{*}{$\begin{array}{l}\text { Penicillium } \\
\text { chrysogenum }\end{array}$} & Petroleum ether & 8.333 & 2.778 \\
\hline & Dichloromethane & 20.000 & 9.455 \\
\hline & $\begin{array}{l}\text { Ethyl acetate } \\
\text { Ethanol }\end{array}$ & 4.444 & 1.158 \\
\hline \multirow{3}{*}{$\begin{array}{l}\text { Aspergillus } \\
\text { niger }\end{array}$} & Petroleum ether & & \\
\hline & Dichloromethane & & \\
\hline & $\begin{array}{l}\text { Ethyl acetate } \\
\text { Ethanol }\end{array}$ & 41.667 & 19.697 \\
\hline
\end{tabular}

\section{Diplostephium revolutum}

Bacteria

Leaf extracts from ethyl acetyl of $D$. revolutum were the only ones that presented antibacterial activity on the study microorganisms (Fig. 5). The highest percentage of inhibition obtained was $44 \%$ in P. aeruginosa followed by $25.4 \%$ in S. aureus and $18.3 \%$ in S. typhi. Most of the samples recorded low percentages of inhibition in E. coli (Table 3).

Fungus

In general, the extracts of $D$. revolutum presented antimicrobial activity on the set of fungi. Table 4 shows that all extracts had inhibitory activity against $C$. albicans, it can also be observed that $A$. niger is sensitive only to ethyl acetate extract and that this is the extract with antimicrobial activity against all fungi (Fig. 6)

\section{DISCUSSION}

The increase in microbial resistance specifically in treatment failure is directly responsible for the current increase morbidity and mortality associated with microbial infections. The use of antibiotics that once regarded as one of the biggest discoveries of the $20^{\text {th }}$ century is effective on saving many lives against bacterial infection. Unfortunately, uncontrolled use of antibiotics, caused from either patients or prescriptions made without cell culture analyses, increased the resistance of bacteria [9]. The medicinal plants are very important to the health of individuals and communities worldwide; this is mainly due to that, most of the drugs derived from herbs are free of side effects or reactions. The herbs have medicinal quality provide rational means for the treatment of many diseases, which are considered of difficult cure [10]. The assessment of the extracts made with the four solvents (petroleum ether, ethyl acetate, ethanol, and dichloromethane) from $D$. phylicoides on E. coli, S. aureus, S. typhi, and P. aeruginosa, as evidenced in Table 1 and Fig. 1a, allowed to determine the sensitivity of these microorganisms to the extracts evaluated. $S$. typhi and P. aeruginosa obtained an inhibition percentage of $3.573 \%$ and $3.333 \%$, respectively; however, the microorganism that obtained greater sensitivity with respect to the other evaluated was $S$. aureus since it presented inhibition percentages of $3.945 \%, 11.403 \%, 32.015 \%$, and $4.320 \%$ for the extracts of petroleum ether, ethyl acetate, ethanol, and dichloromethane, respectively. These results are similar to those obtained by Ávila et al., in 2006 [5], in which the inhibition of $S$. aureus but not of E. coli by flavonoids extracted in Diplostephium tolimense was reported.

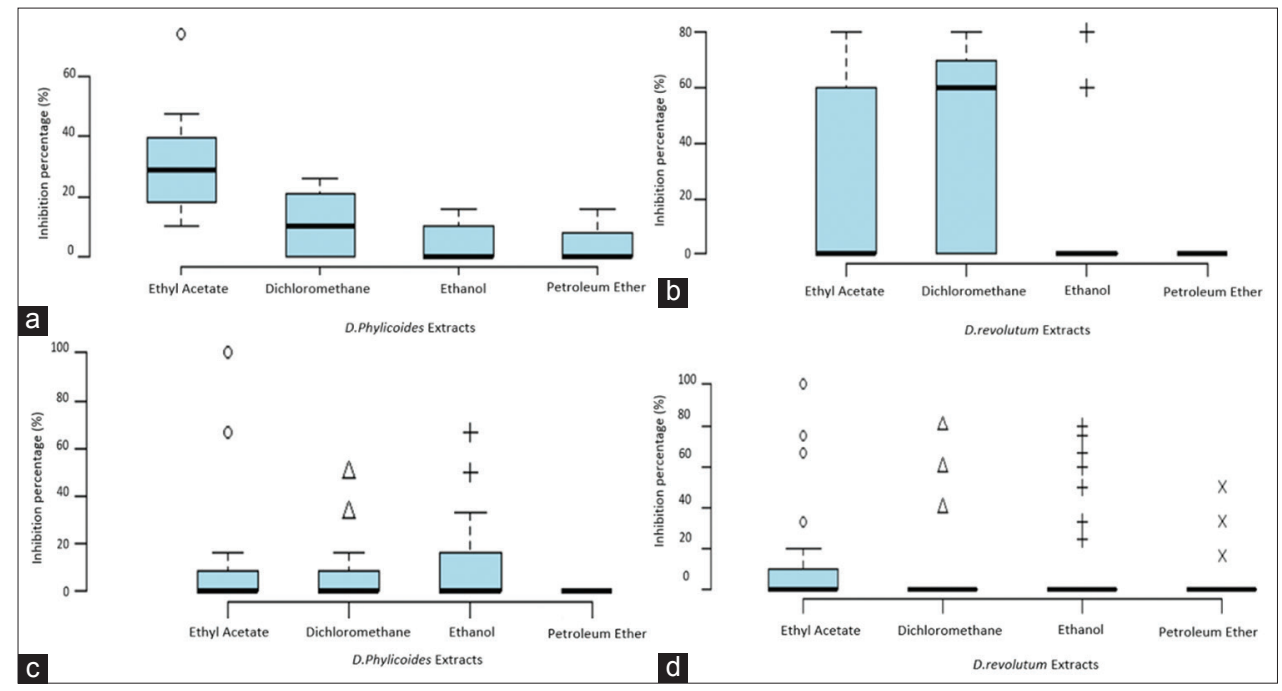

Fig. 1: Distribution of inhibition percentage of Diplostephium phylicoides extracts on Staphylococcus aureus (a) Saccharomyces cerevisiae (b) Candida albicans (c) and Diplostephium revolutum extracts on fungi (d). Extreme, atypical values and median of specific data are determined 


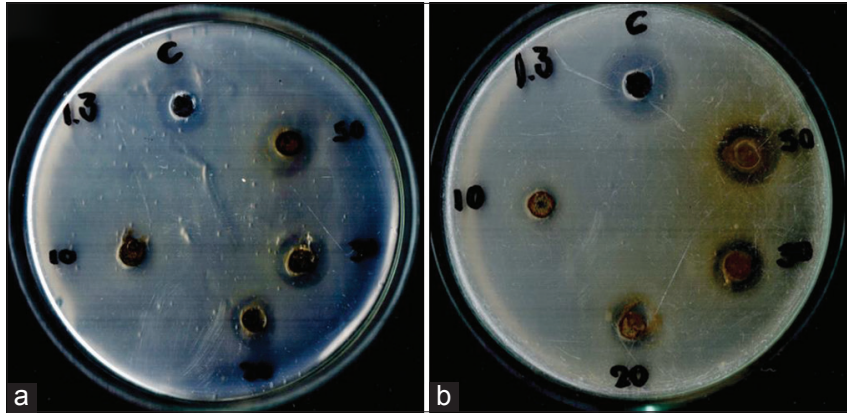

Fig. 2: (a and b) Replicates of inhibition halos of positive control and Diplostephium phylicoides leaf extract obtained from ethyl acetate in Staphylococcus aureus
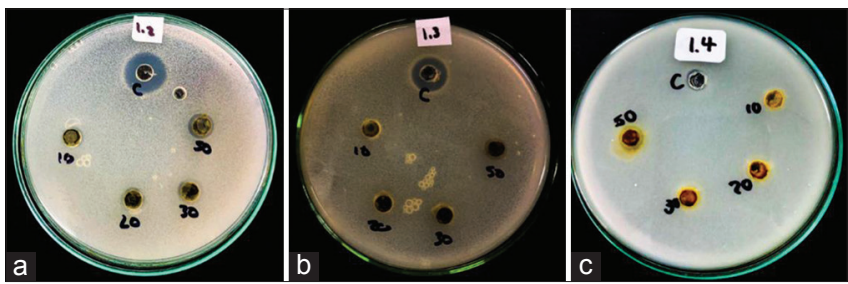

Fig. 3: Inhibition halos of Diplostephium phylicoides leaf extracts obtained from (a) dichloromethane, (b) ethyl acetate, and (c) ethanol in Saccharomyces cerevisiae

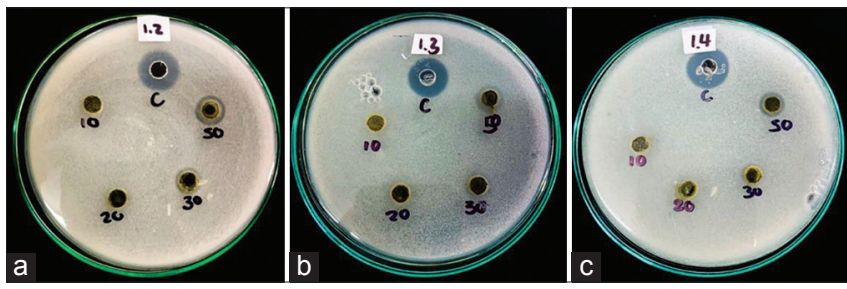

Fig. 4: Inhibition halos of Diplostephium phylicoides leaf extracts obtained from (a) dichloromethane, (b) ethyl acetate, and (c) ethanol in Candida albicans

This antimicrobial activity is due to the presence of the secondary metabolites of the plant in each of the extracts, where ethyl acetate presents a greater inhibition compared to the other extracts since it contains flavonoids such as sorbifolin, genkwanin, and quercetin [8], which have the ability to alter the permeability of microbial membranes [14]. According to Wang et al., in 2017 [14], quercetin is one of the flavonoid compounds with greater antibacterial activity, significantly inhibiting E. coli, S. aureus, P. aeruginosa, and S. enterica, but presenting a stronger bacteriostatic effect in $S$. aureus due to the differences, it presents with Gram-negative bacteria in structure and composition of the cell wall and membrane. A possible explanation that in our results this effect has not occurred in all bacteria is due to low concentrations of this compound. It is important to highlight the results of $S$. aureus against the four extracts since this microorganism is involved in most nosocomial infections. In addition, the resistance to many antibiotics by this microorganism has been pointed out in numerous cases [15], which at some point could cause the results obtained to be applied.

When evaluating the extracts elaborated with the four solvents from $D$. phylicoides on the fungus, the four fungi evaluated to show sensitivity to the extract elaborated with dichloromethane. As shown in Table 2, S. cerevisiae showed an inhibition percentage of $43.333 \%$ in the extract made from dichloromethane, this being the highest inhibition percentage obtained in the test made for fungi with $D$. phylicoides. However, it is not possible to describe the antimicrobial activity

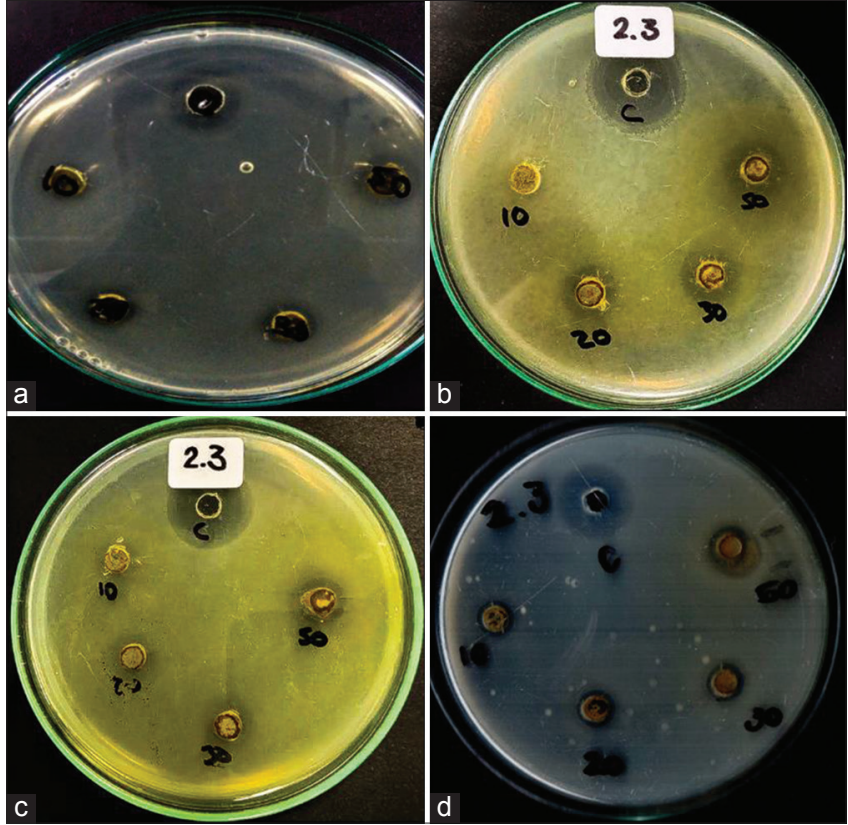

Fig. 5: Inhibition halos of Diplostephium revolutum leaf extract obtained from ethyl acetate in (a) Escherichia coli,

(b) Pseudomonas aeruginosa, (c) Salmonella typhi, and (d) Staphylococcus aureus
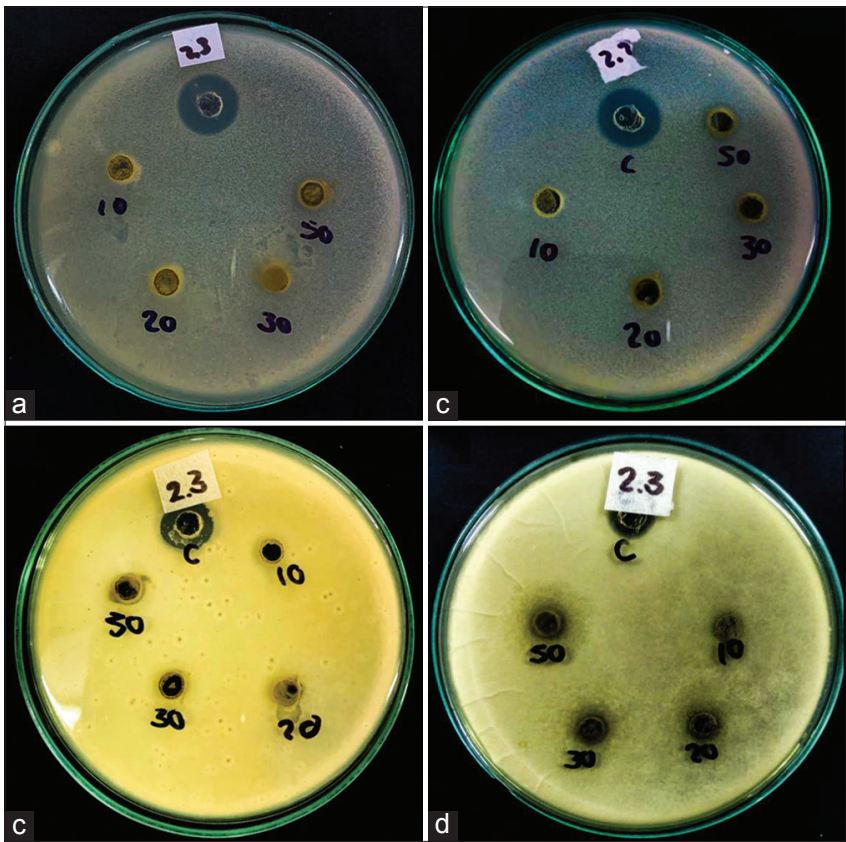

Fig. 6: Inhibition halos of Diplostephium revolutum leaf extracts obtained from ethyl acetate in (a) Candida albicans, (b) Saccharomyces cerevisiae, (c) Penicillium chrysogenum, and (d) Aspergillus niger

performed by dichloromethane extract because no compounds extracted by this solvent have been previously described.

The extract made with ethyl acetate presented antimicrobial activity in S. cerevisiae (Fig. 3), C. albicans (Fig. 4). and P. chrysogenum, this is because this solvent is able to retain flavonoids as mentioned above, which have the ability to inhibit the germination of plant pathogen spores [16]. This is a possible explanation to the antimicrobial activity obtained from this extract against the previously mentioned fungi. In 
addition, the antimicrobial activity against these fungi is consistent with what was proposed by Cushnie and Lamb, in 2005 [16], which indicates that flavonoids can be used against fungal pathogens of human [16]. Structural requirements for antifungal activity have not yet been well defined; however, there is agreement that at least one OH group and some degree of lipophilicity must be present.

The cell wall of filamentous fungi is composed of glucans (30\%-80\%), chitin and chitosan (1\%-15\%), mannan, and glycoproteins, while the cell wall of yeasts differs in the amounts of these compounds, especially chitin $[17,18]$. This difference in composition may be a possible cause of yeast sensitivity to plant extracts, as chitin allows greater resistance to antifungals because its production increases when the cell wall is being affected by some compound, so a cell with high levels of chitin is less susceptible to an antifungal [19]. This matches with our results since a higher percentage of inhibition was observed in yeasts than in filamentous fungi.

In the case of D. revolutum (Table 3 and Fig. 1c), antimicrobial activity was evidenced only in the ethyl acetate extract; however, this inhibition was presented in the four bacteria evaluated (Fig. 5). However, for D. revolutum, no research has been carried out on the compounds to which the previously mentioned antimicrobial activity can be attributed. Although, in preliminary studies of the genus Diplostephium [5-12], compounds such as flavonoids and triterpenes have been determined, which have been described as antimicrobial activity due to the alteration of the lipid bilayer in the plasma membrane, which leads to an alteration of permeability. The differences between the biological activities of terpenes against microorganisms can be explained by differences in the composition of the bacterial wall [20]. According to Castaño et al., in 2010 [21], the greater sensitivity of Gram-negative bacteria with respect to Gram-positive bacteria against the terpenes of Rosmarinus officinalis $\mathrm{L}$. is due to the fact that these interact with the molecules of the membrane, generating destabilization of the lipid bilayer, which leads to increased permeability and alteration of the structure of the membrane. This explains the antimicrobial activity against all evaluated bacteria.

In the evaluation of the fungi against the four extracts of $D$. revolutum, it was determined that the ethyl acetate extract was the most efficient since it presented antimicrobial activity against the four microorganisms evaluated, obtaining percentages of inhibition from $4.444 \%$ to $41.667 \%$ (Table 4 and Fig. 1d) where its greater inhibitory activity was presented against $A$. niger for what it is deduced that the concentrations of the compounds produced in $D$. revolutum are in high concentrations since they were able to inhibit both yeasts and filamentous fungi (Fig. 6).

\section{CONCLUSIONS}

D. revolutum and $D$. phylicoides presented inhibition in yeasts and filamentous fungi, additionally, $D$. revolutum generated inhibition against all bacteria; therefore, it is considered that the extracts of this plant are more effective to have a broad spectrum of inhibition, being the extract made with the ethyl acetate solvent the most effective to obtain significant percentages of inhibition in the tests performed. It should be noted that dichloromethane leaf extract presented high percentages of inhibition against $S$. cerevisiae, while petroleum ether extract presented the lowest antimicrobial activity against the microorganisms evaluated.

\section{ACKNOWLEDGMENTS}

The authors would like to thank Pontificia Universidad Javeriana Bogotá and Labfarve Laboratories for the support and facilities.

\section{AUTHORS' CONTRIBUTIONS}

All authors contribute to design the experiments; Janeth Del Carmen Arias Palacios, Leonardo Peña Carranza, and Natalia Paola Torres Niño performed the experiments. Wrote the paper: Janeth Del Carmen Arias
Palacios, Leonardo Peña Carranza, and Natalia Paola Torres Niño. All authors revised the article critically for important intellectual content.

\section{CONFLICTS OF INTEREST}

We declare that we have no conflicts of interest.

\section{REFERENCES}

1. Organización Mundial de la Salud. Resistencia a Los Antibióticos; 2018. Available from: https://www.who.int/es/news-room/fact-sheets/ detail/resistencia-a-los-antibióticos.

2. Sepúlveda JG, Porta DH, Rocha SM. La participación de los metabolitos secundarios en la defensa de las plantas. Rev Mex Fitopatol 2003;21:355-63. Available from: http://www.redalyc.uaemex.mx.

3. Carrillo HL, Mora C, Alvarez R, Alzate F, Osorio E. Chemical composition and antibacterial activity against Enterobacter cloacae of essential oils from Asteraceae species growing in the páramos of Colombia. Ind Crops Prod 2015;77:108-15.

4. Carbonó DE, Dib DJ. Medicinal plants used by the cogui at palomino river, Sierra Nevada of Santa Marta (Colombia). Caldasia 2013;35:33350. Available from: https://www.jstor.org/stable/90008348.

5. Ávila L, Baquero E, Viña A, Murillo E. Actividad antibacteriana de Diplostephium tolimense Cuatrec. (Asteraceae) frente a Staphylococcus aureus. Vitae 2006;13:55-60.

6. Jardín Botánico de Bogotá José Celestino Mutis. Diplostephium phylicoides (Kunth) Wedd. Available from: http://www.colecciones. jbb.gov.co/herbario.

7. Cuatrecasas J. Prima flora colombiana. Webbia J Plant Taxon Geogr 1969;24:155-65.

8. Rodriguez AO, Torrenegra GR. Flavonoids, terpenes and the antioxidant activity of Diplostephium phylicoides (H.B.K.) Wedd. Indian J Sci Technol 2018;11:1-7.

9. Sharma J, Kumar P. Comparative study of antimicrobial activity and phytochemical screening of serial extracts from: Leaves and fruit of Aegle marmelos and Carica papaya. Int J Pharm Pharm Sci 2017;9:119-23.

10. Hamid IS, Eltayeb IM. In vitro susceptibility of isolated Shigella flexneri and Shigella dysenteriae to the ethanolic extracts of Trachyspermum ammi and Peganum harmala. Int J Pharm Pharm Sci 2019;11:103-6.

11. Thangaraj P. Pharmacological Assays of Plant Based Natural Products, $71^{\text {th }}$ ed. Berlin: Springer International Publishing; 2016.

12. Sequeda CL, Muñoz RC, Celis ZC, Gutiérrez PS, Luengas CP, Gamboa F. Preliminary phytochemical analysis of Berberis goudotii Triana and planch. Ex Wedd. (Berberidaceae) with anticariogenic and antiperiodontal activities. Sci Pharm 2019;87:1-19.

13. Nzogong RT, Ndjateu FS, Ekom SE, Fosso JA, Awouafack MD, Tene M, et al. Antimicrobial and antioxidant activities of triterpenoid and phenolic derivatives from two Cameroonian Melastomataceae plants: Dissotis senegambiensis and Amphiblemma monticola. BMC Complement Altern Med 2018;18:1-11.

14. Wang S, Yao J, Zhou B, Yang J, Chaudry MT, Wang M, et al. Bacteriostatic effect of quercetin as an antibiotic alternative in vivo and its antibacterial mechanism in vitro. J Food Prot 2017;81:68-78.

15. Okoye E, Ezeogo J. Antimicrobial activity of the crude extracts of Hamelia patens on Some selected clinical samples. J Complement Altern Med Res 2017;1:1-7.

16. Cushnie TP, Lamb AJ. Antimicrobial activity of flavonoids. Int $\mathrm{J}$ Antimicrob Agents 2005;26:343-56.

17. Aranda MA, Lopez MF, Lopez LL. Cell wall composition plays a key role on sensitivity of filamentous fungi to chitosan. J Basic Microbiol 2016;56:1059-70.

18. Luo Y, Wang J, Liu B, Wang Z, Yuan Y, Yue T. Effect of yeast cell morphology, cell wall physical structure and chemical composition on patulin adsorption. PLoS One 2015;10:1-16.

19. Munro CA. Chitin and glucan, the yin and yang of the fungal cell wall, implications for antifungal drug discovery and therapy. Adv Appl Microbiol 2013;83:145-72.

20. Bueno SJ, Martinez MJ, Stashenko E. Actividad antimicobacteriana de terpenos. Rev Univ Ind Santander 2009;41:231-5.

21. Castaño HI, Ciro G, Zapata JE, Jiménez SL. Actividad bactericida del extracto etanólico y del aceite esencial de hojas de Rosmarinus officinalis L. Sobre algunas bacterias de interés alimentario. Vitae 2010;17:149-54. 